Jurnal Indonesia Sosial Teknologi: p-ISSN: 2723 - 6609

e-ISSN : 2745-5254

Vol. 2, No. 1 Januari 2021

\title{
PENGARUH BAURAN PEMASARAN TERHADAP PENJUALAN FOOD AND BEVERAGE BUSINESS
}

\author{
Aldo Leonardo, Kevin Budiono Vivien Oskar dan Nova Irene Bernedeta Sitorus \\ Universitas Pelita Harapan \\ Email: aldo_leonardotan@yahoo.com, kevinbudiono001@gmail.com \\ vivienoskar01@gmail.com,nova.sitorus@uph.edu
}

\section{Abstract}

This research was conducted to determine the effect of the marketing mix on the sales of culinary businesses during the Covid-19 pandemic, because during the Covid-19 pandemic, there were many culinary businesses that were in trouble and experienced a decline. This research was conducted in the Tangerang and South Tangerang areas. The formulation of the problem of this research is to find out how the development of the Food and Beverage business during the Covid-19 pandemic in South Tangerang and Tangerang as well. How is the influence of the marketing mix on the Food and Beverage business during the Covid-19 pandemic in South Tangerang and Tangerang. This study aims to provide information about the factors that influence the sales of culinary businesses. These factors include product, second is Place, third is Price. The fourth factor is Promotion, the fifth is People, the sixth is Packaging, the seventh is Programming, the eighth is Partnership. Marketing mix is an important element in marketing so that it becomes the main object of this research. The research method used in this research is descriptive quantitative research method,time dimension cross sectional, has a high research generation, real environment, industrial analysis unit, uses non-purposive sampling, collects data with a questionnaire, and has 28 indicators as a tool. measuring variables of the study, the collected data will then be processed using PLS for analysis descriptive statistics, test reliability, validity, multikolinearitas, hypothesis testing partial test of discriminant validity, and test $R^{2}$ to ensure data is unfit, then the last stage is a test $T$ for hypothesis testing.

Keyword: marketing mix; sales; tourism; food and drink business; food \& beverage

\begin{abstract}
Abstrak
Penelitian ini dilakukan untuk mengetahui perngaruh bauran pemasaran terhadap penjualan usaha kuliner pada masa pandemic covid-19 ini, karena pada masa pandemi covid-19 ini banyak sekali usaha kuliner yang kesusahan dan mengalami penurunan, penelitan ini dilakukan pada daerah Tangerang dan Tangerang Selatan. Adapun rumusan masalah daripada penelitian ini adalah untuk mengetahui Bagaimana perkembangan Food and Beverage business selama pandemi Covid-19 di Tangerang Selatan dan Tangerang dan juga. Bagaimana Pengaruh bauran pemasaran terhadap Food and Beverage business pada masa pandemic Covid-19 di Tangerang Selatan dan Tangerang. Penelitian ini bertujuan memberikan keterangan tentang faktor yang memengaruhi penjualan usaha kuliner. Faktor-faktor tersebut
\end{abstract}


diantara lain adalah product, kedua ialah Place, yang ketiga merupakan Price. Faktor keempat merupakan Promotion yang kelima merupakan People, yang keenam merupakan Packaging, yang ketujuh merupakan Programming, yang kedelapan merupakan Partnership. Bauran Pemasaran merupakan unsur penting dalam pemasaran sehingga menjadi objek utama penelitian ini. Metode Penelitian yang digunakan dalam penelitian ini adalah metode penelitian kuantitatif deskriptif, dimensi waktu cross sectional, memiliki generelisasi riset yang tinggi, lingukngan riil, unit analisis industri, menggunakan penentuan sample dengan non purposive sampling, mengumpulkan data dengan kuesioner, dan mempunyai 28 indikator sebagai alat ukur variabel penelitian, Data yang terkumpul tersebut kemudian akan diolah menggunakan PLS untuk Analisa statistic deskriptif, uji reabilitas, validitas, uji multikolinearitas, uji hipotesis parsial, uji diskriminan validitas, dan Uji $\mathrm{R}^{2}$ untuk memastikan data layak dipakai, kemudian tahap terakhir adalah Uji $\mathrm{T}$ untuk pengujian hipotesis.

Kata kunci: bauran pemasaran; penjualan; pariwisata; usaha makan dan minum; food \& beverage

\section{Pendahuluan}

Indonesia merupakan Negara berkembang yang mempunyai banyak potensi Alam dan juga mempunyai sektor ekonomi yang sedang berkembang. Tetapi pada Tahun 2020 ini Indonesia sedang di landa sebuah pandemic yaitu Covid-19, menurut World Health Organisation (WHO) Covid-19 ini merupakan penyakit yang disebabkan oleh Novel Corona Virus dimana penyakit ini menyerang sistem pernafasan daripada orang yang terkena infeksi virus ini ( $\mathrm{Zu}$ et al., 2020). Dilansir dari jurnal penelitian "Dampak Pandemi COVID-19 Terhadap Bisnis dan Eksistensi Platform Online" bidang usaha yang terpengaruh oleh covid-19 adalah bisnis transportasi umum, Pariwisata, Perhotelan, pusat perbelanjaan, serta pedagangan offline karena bisnis ini bergantung pada kunjungan konsumen secara langsung (Taufik \& Ayuningtyas, 2020)

Covid-19 mempengaruhi bidang-bidang bisnis tersebut karena dengan adanya Covid-19 ini banyak daerah di Indonesia menjalani kebijakan pembatasan sosial berskala besar (PSBB) untuk menekan penyebaran Virus tersebut dimana dalam pelaksanaan PSBB banyak sekali pusat hiburan yang ditutup termasuk hotel dan restoran, salah satu daerah yang terdampak kejadian tersebut adalah Tangerang Selatan. Dilansir dari Tribunnews ketua Perhimpunan Hotel dan Restoran Indonesia (PHRI) Gusri Effendi mengatakan bahwa 80 persen dari restoran hotel dan restoran tutup di tengah situasi pandemi ini dan penutupan hotel dan restoran tersebut menyebabkan PHK (pemutusan hubungan kerja) dari pada karyawan-karyawan yang bekerja disana, walikota Tangerang Selatan Benyamin Davnie pun mengatakan bahwa jumlah karyawan yang terkena PHK pada bulan April 2020 sebanyak 1403 tenaga kerja (Wartakota.Tribunews,2020). Hal-hal tersebut bisa terjadi karena terjadi penurunan mobilitas masyarakat untuk mencegah penyebaran virus corona, dan penurunan mobilitas itu akhirnya berdampak pada sektor pariwsata yang membutuhkan mobilitas daripada masyarakat itu sendiri dan akhirnya menyebabkan penurunan pada sektor ekonomi pariwisata. 
Table 1

Laju Pertumbuhan PDRP Usaha Kuliner

\begin{tabular}{|l|ccc|}
\hline & Lapangan Usaha & $\begin{array}{c}\text { Triwulan I-2020 } \\
\text { terhadap Triwulan IV } \\
\mathbf{2 0 1 9}(\mathbf{q}-\mathbf{t o}-\mathbf{q})\end{array}$ & $\begin{array}{c}\text { Triwulan II-2020 } \\
\text { terhadap Triwulan I- } \\
\mathbf{2 0 2 0} \text { (q-to-q) }\end{array}$ \\
\hline 1. & $\begin{array}{l}\text { Penyediaan Akomodasi } \\
\text { dan Makan Minum }\end{array}$ & $-0,28$ & $-14,70$ \\
\hline
\end{tabular}

Sumber : Badan Pusat Statistik (2020)

Dapat kita lihat laju PDRB dari penyedia akomodasi makan minum jika dibandingkan dari Triwulan IV 2019 sampai ke Triwulan I 2020 mengalami penurunan sebesar 0,28\% dan kemudian turun lagi pada Triwulan II 2020 sebesar 14,70 \%, hal ini membuktikan bahwa Covid-19 sangat berdampak pada akomodasi makan dan minum yang ada di Provinsi Banten. Penurunan ini disebabkan oleh Covid-19 yang menyabakan restoran tidak siap dalam menghadapi sebuah skenario pandemic.

Dalam sebuah usaha pariwisata terutama F\&B salah satu factor yang dapat meningkatkan Penjualan adalah Marketing yang mempunyai beberapa aspek yang disebut dengan bauran pemasaran. Menurut ( Morrison 2010) bauran pemasaran terdiri dari 8P (product, place, price, promotion, programming, packaging, partnership, people).Hal ini menunjukan bahwa dengan bauran pemasaran yang tepat maka usaha dalam bidang pariwisata dapat berjalan dengan baik, sedangkan banyak sekali Food and Beverage business yang tutup dan gagal pada saat pandemi karena tidak dapat menyesuaikan Bauran Pemasaran mereka terhadap situasi Pandemi. Maka dari itu Penulis ingin meneliti pengaruh bauran pemasaran pada Food and Beverage business saat masa pandemic covid-19 dan juga mencari solusi penyesuaian 8P untuk Food and Beverage business dalam menghadapi Situasi Pandemi.

Tujuan penelitian ini adalah Mengetahui pengaruh bauran pemasaran Product terhadap penjualan Usaha Kuliner pada masa pandemi Covid-19 di Tangerang Selatan dan Tangerang. Mengetahui pengaruh bauran pemasaran Place terhadap terhadap penjualan Usaha Kuliner pada masa pandemic Covid-19 di Tangerang Selatan dan Tangerang.

\section{Hasil penelitian terdahulu}

\begin{tabular}{llllll}
\hline NO & Peneliti & Judul & Metode & Variable & Hasil \\
\hline 1 & Nurcahyo, & PENGARUH & Penelitian & Variable & Bauran Pemasaran \\
& Fandry & BAURAN & kasual & Terikat & memiliki pengaruh \\
& Wahyuati, & PEMASARAN & komparatif, & Y =Volume & yang signifikan \\
& Aniek & TERHADAP & analisis regresi & penjualan & terhadap volume \\
& $(2016)$ & VOLUME & linear & Variable bebas & penjualan \\
& PENJUALAN & Berganda, & Prod =produk & Unsur bauran \\
& PADA & Uji validitas, & Pro =promosi & pemasaran dengan \\
& RESTORAN & Uji reabilitas, & Har =harga & pengaruh tersbesar \\
& MCDONALD'S & Uji Asumsi & Temp =tempat & adalah \\
& DELTA PLAZA & klasik & & Tempat (Temp) \\
& SURABAYA & Uji normalitas & & dan berpengaruh \\
& & Uji & & paling kecil adalah \\
& & heteroskedastia & & \\
\hline
\end{tabular}




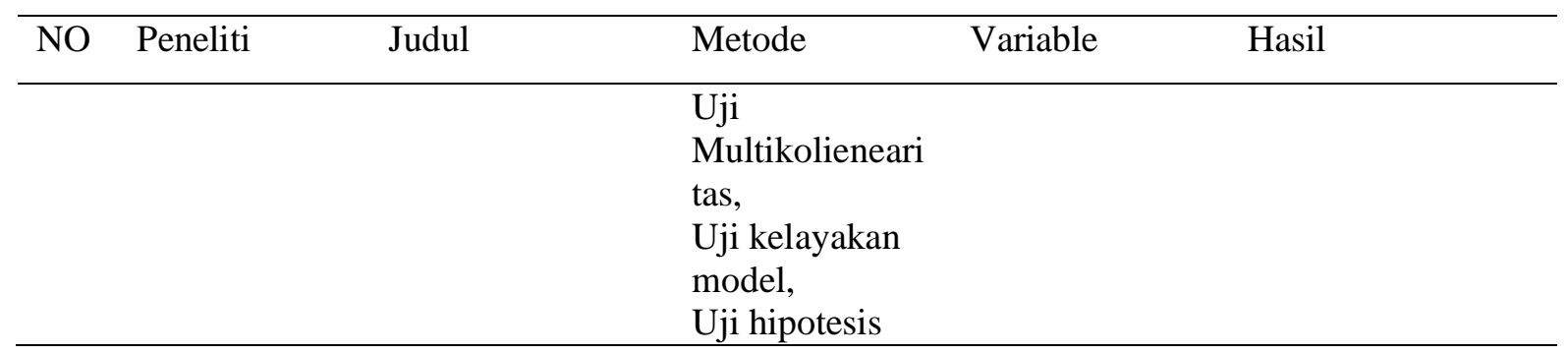

Perbedaan penelitian yang dilakukan oleh peneliti ada di jumlah variabel dan juga pada tahap uji data dan juga pada jenis penelitian. Penelitian ini mempunyai 7 variabel eksogen dan 1 variabel endogen, kemudian perbedaan pada tahap uji data dapat dilihat pada penelitian ini tidak terdapat uji heterokedastias, dan jenis penelitian ini adalah kuantitatif eksplanatif bukan komparatif. Dan uji data pada penelitian ini menggunakan PLS dan bukan menggunakan SPSS.

\section{P Marketing Mix}

Menurut ( Morrison 2010) ada 8 komponen bauran pemasaran yaitu sebagai berikut:

\section{a. Product}

produk dalam bauran pemasaran dapat diartikan sebagai rangkaian produk atau fasilitas yang disediakan oleh perorangan, organisasi, atau destinasi untuk para pelanggan.

b. Price

price dalam bauran pemasaran berfokus pada value for money, dimana konsumen membandingkan jumlah uang yang dia bayar dengan pelayanan dan barang yang ia dapat, untuk menentukan value.

c. People

People merupakan komponen SDM dari suatu usaha, baik mulai dari karyawan, manajer, dan juga pelanggan. SDM yang baik tentunya akan menghasilkan kinerja yang maksimal

d. Place

place yang dimaksud adalah saluran distribusi yang mempunyai pengertian rangkaian sistem atau perantara yang harus dilewati produk atau layanan sebelum sampai ke konsumen

e. Promotion

fungsi utama dari promosi selaku bagian dari pemasaran adalah untuk mengkomunikasikan informasi tentang produk dan layanan kepada konsumen ataupun calon konsumen.

\section{f. Packaging}

Packaging yang dimaksud adalah cara perusahaan mengkombinasikan produk utama atau layanan utama dengan produk dan layanan tambahan dan dijadikan menjadi satu harga.

\section{g. Partnership}

Partnership yang dimaksud adalah kegiatan promosi atau pemasaran yang dilakukan secara kooperatif oleh perusahaan dan organisasi pariwisata, atau perusahaan lainnya dan bersifat saling menguntungkan.

\section{h. Programming}


Progreming adalah acara, program, atau promo khusus pada jangka waktu tertentu yang sudah ditentukan untuk meningkatkan pengeluaran pembelian pelanggan atau untuk menambah daya Tarik

\section{Pengertian Penjualan}

Menurut ( Downes \& Goodman 2018) sales adalah pendapatan diterima oleh perusahaan dari penjualan barang atau jasa dalam jangka waktu tertentu. Performa dari suatu perusahaan dapat dilihat dari volume penjualan perusahaan tersebut dari waktu ke waktu, perusahaan yang baik tentunya mempunyai volume penjualan kondisi volume penjualan yang mencapai target. Menurut ( Kotler \& Keller 2016) terdapat tiga buah indikator untuk penjualan yaitu pencapaian target volume penjualan, mendapatkan laba, dan menunjang perkembangan perusahaan.

\section{Kerangka Konseptual}

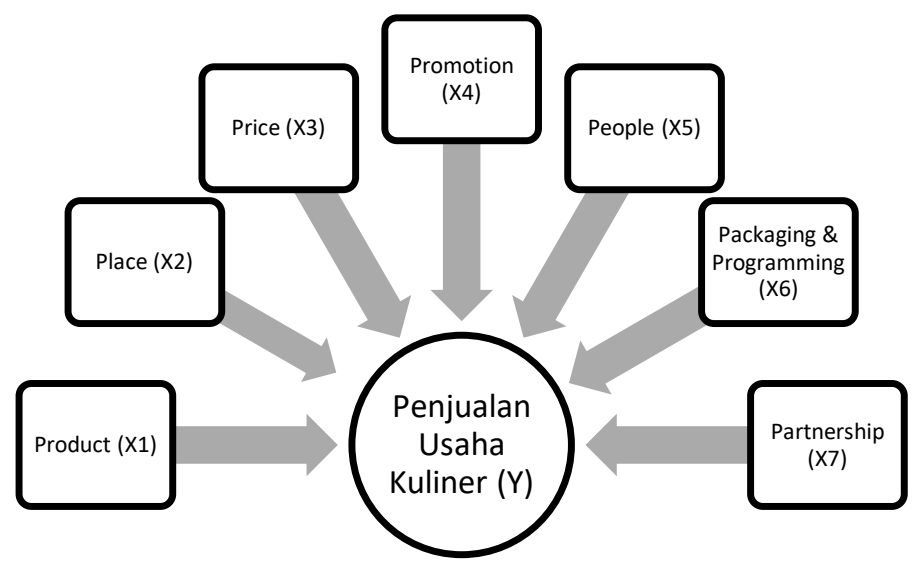

\section{Metode Penelitian}

Penelitian berlangsung di kota Tangerang Selatan dan Kabupaten Tangerang, jenis penelitian yang dilakukan adalah kuantitatif Menurut ( Hair 2019) penelitian kuantitatif adalah penelitian yang datanya dapat diukur dengan menggunakan instrumen pengukuran dan kemudian akan diolah, penelitian kuantitatif menggunakan data berbentuk angka yang dapat di olah, menurut ( Hair 2019) riset eksplanatif adalah untuk menjelaskan hubungan antar variabel, dan biasanya dimulai dengan pertanyaan bagaimana dan kenapa.. Kemudian Pengujian hipotesis menggunakan uji hipotesis kausalitas dimana menjelaskan hubungan sebab akibat antar variable bebas dan variable terikat. Dimensi waktu yang dipilih cross sectional karena penelitian pengumpulan data dari pertanyaan riset dilakukan pada satu waktu saja. Riset ini merupakan riset yang tidak mendalami satu objek melainkan riset yang memiliki generalisasi yang tinggi karena meriset usaha kuliner yang ada di daerah Kabupaten Tangerang dan Kota Tangerang Selatan sehingga mempunyai banyak objek penelitian yang diteliti secara umum. Penelitian ini menggunakan lingkungan riil karena meneliti sebuah peristiwa di kehidupan nyata tanpa ada intervensi dari peneliti dan tanpa adanya uji lab dimana harus membuat sebuah kondisi tertentu terhadap objek penelitian untuk dapat diteliti. Unit analisis daripada penelitian ini adalah pada level Industri karena yang diteliti adalah industri Penyedia akomodasi makan dan minum. Instrumen riset yang digunakan dalam penelitian ini adalah kuesioner yang dibagikan melalui google form dan juga aplikasi penghitung statistic PLS. Penelitian ini menggunakan menggumpulkan sampel dengan 
menggunakan jenis Non-Probability Purposive Sampling dimana dengan menggunakan Teknik ini peneliti memilih responden tidak secara acak melainkan dengan alasan tertentu, sehingga tidak semua bagian populasi dapat menjadi sampel, peneliti memilih responden yang paling cocok dengan karakteristik yang diinginkan peneliti sehingga dapat menjawab pertanyaan yang diberi dengan maksimal. Menurut Hair (2019) Jumlah sample minimum untuk pertanyaan penelitian pervariable yang ditanyakan adalah lima kali dari jumlah variable yang dianalisa, dan kuesioner mempunyai 28 indikator dan jika dikali lima akan menjadi 140 Responden. Metode pengumpulan data yang dipilih adalah melalui kuesioner google form, para responden akan diberi link untuk mengisi kuesioner yang akan dijawab menggunakan skala likert dari skala satu sampai enam (sangat tidak setuju, tidak setuju, agak tidak setuju, agak setuju, setuju, sangat setuju). Ada pun indikator variabel pada penelitian ini adalah sebagai berikut :

Table 3

Indikator Penelitian

\begin{tabular}{|c|c|}
\hline Variable & Pengukuran \\
\hline \multirow[t]{3}{*}{ Product (X1) } & Variasi Produk \\
\hline & Kualitas Produk \\
\hline & Kebersihan produk \\
\hline \multirow[t]{2}{*}{ Place (X2) } & Saluran Distribusi Langsung \\
\hline & Saluran Distribusi tidak langsung \\
\hline \multirow[t]{4}{*}{ Price $(\mathrm{X3})$} & Value for money \\
\hline & Unsophisticated approach \\
\hline & Sophisticated approach \\
\hline & Multistage approach \\
\hline \multirow[t]{5}{*}{ Promotion (X4) } & Advertising \\
\hline & Personal selling \\
\hline & Sales promotion \\
\hline & Merchandising \\
\hline & publicity \\
\hline \multirow{3}{*}{ People (X5) } & Process Approach \\
\hline & Customer Focus \\
\hline & Involvement of People \\
\hline \multirow[t]{2}{*}{ Packaging\& Programming (X6) } & $\begin{array}{l}\text { Pemaketan produk utama dilengkapi } \\
\text { dengan produk pelengkap diberikan } \\
\text { dengan satu harga }\end{array}$ \\
\hline & $\begin{array}{l}\text { Membuat program untuk jangka } \\
\text { waktu tertentu untuk merayakan hari } \\
\text { tertentu tanpa dilengkapi dengan } \\
\text { promosi penjualan dan juga } \\
\text { pemaketan produk }\end{array}$ \\
\hline
\end{tabular}




\begin{tabular}{ll} 
& $\begin{array}{l}\text { Mengikuti hari-hari besar yang ada } \\
\text { untuk membuat program penjualan }\end{array}$ \\
\hline Partnership (X7) & $\begin{array}{l}\text { Customer } \\
\text { Organizations in the same business }\end{array}$ \\
\hline & $\begin{array}{l}\text { Organizations in related business } \\
\text { Organizations in non related } \\
\text { business }\end{array}$ \\
\hline Online alliances \\
\hline Penjualan Usaha Kuliner (Y) & Volume Penjualan \\
\hline & Laba \\
\hline & Menunjang pertumbuhan \\
\hline
\end{tabular}

Sumber : Hasil Olahan Data (2020)

Metode Analisi Data yang dipakai dalam penelitian ini adalah sebagai berikut :

\section{Analisis Statistik Deskriptif}

Menurut (Creswell 2018) penelitian kuantitatif adalah sebuah riset yang digunakan untuk menjelaskan hubungan antar variable, dan nantinya data yang telah dikumpulkan akan dihitung dengan oleh alat bantu statistik.PLS (Partial Least Square). Penelitian ini menggunakan Teknik analisis data adalah metode statistik deskriptif dan statistik infrensial. Menurut ( Sugiyono 2017) Statistik deskriptif adalah statistik yang berfungsi menganalisis data dengan cara mendeskripsikan atau menggambarkan data yang telah terkumpul apa adanya tanpa bermaksud untuk membuat kesimpulan yang berlaku untuk umum. Sedangkan statistik inferensial merupakan teknik statistik yang digunakan untuk menganalisis data sampel dan hasilnya diberlakukan untuk populasi Analisis data menggunakan skala likert.

\section{Pengujian kualitas Data Uji Validitas}

Pada penlitian ini, digunakan Average Variance Extracted (AVE) untuk mengukur validitas. Menurut ( Hair 2019) nilai AVE minimal 0,50 menunjukan ukuran convergent validity yang baik, artinya variabel laten dapat dapat menjelaskan rata-rata lebih dari setengah keragaman indikator-indikatornya. Selain mengukur validitas variabel dengan menggunakan AVE, indikator dalam penelitian ini juga melalui tes discriminant validity. Menurut Hair (2019) adalah perbedaan atau keunikan konstruk yang membedakan dia daripada konstruk lainnya.

\section{Uji Reliabilitas}

Reliabilitas merupakan sebuah pengkuran tingkat kepercayaan sebuah alat ukur, artinya apabila suatu instrumen digunakan berulang - ulang untuk mengukur suatu yang sama, maka hasilnya relatif stabil. Teknik yang digunakan dalam penelitian ini untuk mengukur Reliabilitas adalah Composite Reliability dimana dia mengukur reliabilitas internal dan nilai composite realiabiility harus berada di atas 0,70 . 


\section{Pengujian Hipotesis \\ Uji Multikolinearitas}

Uji ini berfungsi untuk menemukan apakah ada hubungan korelasi antar variabel eksogen. Untuk melihat hasil multikolinearitas, dapat dilihat dengan melihat nilai tolerance value dan variance inflation factor (VIF). Nilai yang umum dipakai untuk menunjukkan adanya mulitkolonieritas adalah apabila nilai Tolerance Value $<0,01$ atau nilai VIF > 10 maka terjadi multikolineritas antara variabel independennya.

\section{Uji Hipotesis Parsial (UJI T)}

Penelitian ini menggunakan metode uji hipotesis parsial atau yang dikenal dengan uji T. Uji T dilakukan untuk mengetahui apakah variabel eksogen $\mathrm{X} 1$ sampai X8 mempunyai pengaruh terhadap variabel endogen yaitu Y.

Kriteria yang dapat digunakan untuk uji $\mathrm{T}$ adalah:

1. Jika t hitung $>\mathrm{t}$ tabel $(\alpha=0,05)$, maka $\mathrm{H} 0$ ditolak, Ha diterima.

2. Jika t hitung $<\mathrm{t}$ tabel $(\alpha=0,05)$, maka H0 diterima, Ha ditolak. Diketahui nilai t tabel tingkat kepercayaan $95 \%$

\section{Uji diskriminan validitas}

Uji discriminant validity bertujuan untuk membuktikan bahwa indikator tersebut berbeda dengan indikator lainnya. Suatu indikator dinyatakan memenuhi diskriminan validity. apabila nilai cross loading indikator pada variabelnya adalah yang terbesar dibandingkan pada variabel lainnya. Jika nilai cross loading indikator pada variabelnya adalah yang terbesar dibandingkan pada variabel lainnya maka data dikatakan valid.

\section{Uji Koefisien determinan $\mathbf{R}^{2}$}

Koefisien Determinan $\left(\mathrm{R}^{2}\right)$ merupakan alat untuk mengukur akurasi kemampuan variabel eksogen $(\mathrm{X})$ memprediksi variabel endogen $(\mathrm{Y})$. Nilai koefisien determinasi adalah antara nol atau satu. Jika nilai koefisien determinan sama dengan 1, maka variabel independen memberikan hampir semua informasi yang dibutuhkan untuk memprediksi variabel independen. Sedangkan jika nilai koefisien determinan sama dengan nol, maka variabel independen dalam menjelaskan variabel dependen tidak berkontribusi. Penilaian goodness of fit yang di gunakan diketahui dari nilai Q- Square. Nilai Q-Square memiliki arti yang sama dengan coefficient determination ( $\mathrm{R}$-Square) pada analisis regresi, dimana semakin tinggi Q-Square, maka model dapat dikatakan semakin baik atau semakin fit dengan data.

\section{Hasil dan Pembahasan}

Penelitian yang dilakukan merupakan penelitian kuantitatif deskriptif, dan data yang didapat dikumpulkan menggunakan kuesioner yang disebarkan secara online. Target sample yang dipilih adalah pemilik usaha kuliner yang berdomisili di Tangerang dan Tangerang Selatan, kuesioner disebarkan dari 30 desember 2020 sampai 1 januari 2021, disebarkan kepada 140 responden. Usia Responden termuda 17 tahun dan yang tertua 54 tahun, dan responden mempunyai rentang usia 17-27 tahun sebanyak 119 responden (85\%), 28-38 tahun 12 responden (8,5\%), 39-49 tahun 7 responden $(5 \%), 50-$ 60 tahun 2 responden $(1,4 \%)$. Kemudian pendapatan terkecil responden adalah sebesar Rp. 1.000.000 dan pendapatan terbesar responden adalah sebesar Rp. 85.000.000, responden memiliki rentang pendapatan Rp. 1.000.000-15.000.000 sebanyak 124 responden (88\%), kemudian 15.000.001-29.000.001 sebanyak 8 responden $(5,7 \%)$, 
kemudian 43.000.003-57.000.003 sebanyak 5 responden (3,5\%), kemudian 57.000.00471.000.004 sebanyak 2 responden (1,4\%), kemudian 71.000.005-85.000.005 sebanyak 1 responden $(0,7 \%)$. Responden yang dipilih berdomisili di daerah Tangerang dan Tangerang selatan, $69(49,3 \%)$ responden di Tangerang dan 71 (50,3\%) responden di Tangerang Selatan. Pekerjaan Responden beragam mulai dari wiraswasta 28 responden (20\%), pegawai negeri 7 responden (5\%), pegawai swasta 10 responden $(7,1 \%)$, mahasiswa 64 responden $(45,7 \%)$, pekerjaan lainnya sebesar 31 responden $(22,1 \%)$.

\section{Model Uji Hipotesis}

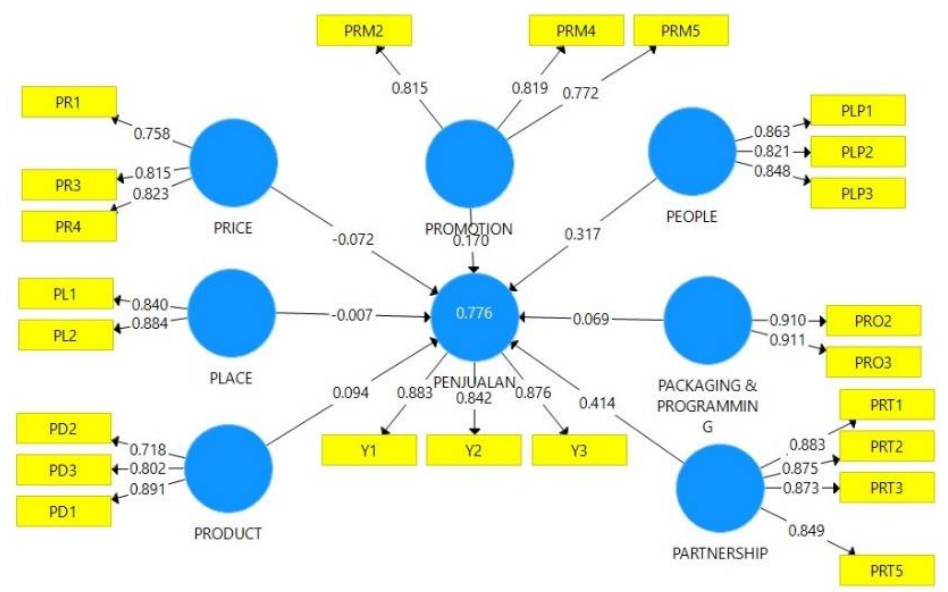

Sumber : Hasil Olahan Data (2020)

Gambar 2 Hasil Uji Algoritma PLS

Hasil Uji PLS pada gambar 4 menunjukan bahwa Bauran Pemasaran X1 sampai X8 mempunyai pengaruh sebesar $77,6 \%$ terhadap variabel endogen Penjualan (Y). Pengaruh masing-masing variabel dapat dijabarkan sebagai berikut Product X1 mempunyai pengaruh sebesar 9,4\%, Place X2 mempunyai pengaruh sebesar $-0,7 \%$, kemudian Price (X3) mempunyai -7,2\%, Promotion (X4) mempunyai pengaruh sebesar $17 \%$, People (X5) mempunyai pengaruh sebesar 31,7 \%, Packaging \& Programming (X6) mempunyai pengaruh sebesar 6,9\%, , Partnership (X8) mempunyai pengaruh sebesar $41,4 \%$.

\section{Pengkuran Data}

\section{Uji Validitas dan Reabilitas}

Table 4

Hasil Uji Construct Realibility and Validity

\begin{tabular}{lrr}
\hline \multicolumn{1}{c}{ Variabel } & \multicolumn{1}{c}{$\begin{array}{l}\text { Composite } \\
\text { Reliability }\end{array}$} & \multicolumn{1}{c}{ AVE } \\
\hline PACKAGING \& PROGRAMMING & 0,906 & 0,829 \\
\hline PARTNERSHIP & 0,926 & 0,757 \\
\hline PENJUALAN & 0,901 & 0,752 \\
\hline PEOPLE & 0,882 & 0,713 \\
\hline PLACE_ & 0,853 & 0,744 \\
\hline PRICE_ & 0,841 & 0,639 \\
\hline PRODUCT & 0,847 & 0,651 \\
\hline PROMOTION & 0,844 & 0,643 \\
\hline
\end{tabular}

Sumber : Hasil Olahan Data (2020) 


\section{Hasil Uji Validitas}

Berdasarkan tabel 9 dapat dilihat hasil Average Variance Extracted (AVE) daripada variabel Product (X1) adalah sebesar 0,651, Place (X2) adalah sebesar 0,744, Price (X3) adalah sebesar 0,639, Promotion (X4) adalah sebesar 0,643, People (X5) adalah sebesar 0,713, Packaging \& Programming (X6) adalah sebesar 0,829, Partnership (X7) adalah sebesar 0,757. Nilai AVE dari setiap variabel lebih dari 0,50 maka semua variabel dinyatakan valid.

\section{Hasil Uji Realibilitas}

Berdasarkan tabel 9 dapat dilihat hasil Composite Reliability daripada variabel Product (X1) adalah sebesar 0,847, Place (X2) adalah sebesar 0,853, Price (X3) adalah sebesar 0,841, Promotion (X4) adalah sebesar 0,844, People (X5) adalah sebesar 0,882, Packaging\& Programming (X6) adalah sebesar 0,906, Partnership (X7) adalah sebesar 0,926 . Nilai AVE dari setiap variabel lebih dari 0,70 maka semua variabel dinyatakan valid.

\section{Hasil Outer Loading}

\section{Table 5}

Hasil Uji Outer Loading \begin{tabular}{l|l} 
Variabel & Outer Loading
\end{tabular}

\begin{tabular}{|c|c|c|}
\hline \multicolumn{2}{|r|}{ Variabel } & Outer Loading \\
\hline \multicolumn{3}{|c|}{ Product $(X 1)$} \\
\hline PD2 & Variasi Produk & 0,718 \\
\hline PD1 & Kualitas Produk & 0,890 \\
\hline PD3 & Kebersihan produk & 0,802 \\
\hline \multicolumn{3}{|c|}{ Place (X2) } \\
\hline PL1 & Saluran Distribusi Langsung & 0,840 \\
\hline PL2 & Saluran Distribusi tidak langsung & 0,884 \\
\hline \multicolumn{3}{|c|}{ Price $(\mathrm{X} 3)$} \\
\hline PR1 & Value for money & 0,758 \\
\hline PR3 & Sophisticated approach & 0,815 \\
\hline PR4 & Multistage approach & 0,823 \\
\hline \multicolumn{3}{|c|}{ Promotion $(\mathrm{X} 4)$} \\
\hline PRM2 & Personal selling & 0,698 \\
\hline PRM4 & Merchandising & 0,792 \\
\hline PRM5 & publicity & 0,737 \\
\hline \multicolumn{3}{|c|}{ People (X5) } \\
\hline PLP1 & Process Approach & 0,863 \\
\hline PLP2 & Customer Focus & 0,821 \\
\hline PLP3 & Involvement of People & 0,848 \\
\hline \multicolumn{3}{|c|}{ Packaging \& Programming (X6) } \\
\hline PRO1 & $\begin{array}{l}\text { Membuat program untuk jangka } \\
\text { waktu tertentu untuk merayakan } \\
\text { hari tertentu tanpa dilengkapi }\end{array}$ & 0,910 \\
\hline
\end{tabular}




\begin{tabular}{ll|c}
\multicolumn{1}{c|}{ Variabel } & Outer Loading \\
\hline PRO2 & $\begin{array}{l}\text { dengan promosi penjualan dan } \\
\text { juga pemaketan produk }\end{array}$ & $\begin{array}{l}\text { Mengikuti hari-hari besar yang } \\
\text { ada untuk membuat program } \\
\text { penjualan }\end{array}$ \\
\hline
\end{tabular}

\begin{tabular}{lll}
\hline \multicolumn{1}{c}{ Partnership (X8) } \\
\hline PRT1 & Customer & 0,883 \\
\hline PRT2 & $\begin{array}{l}\text { Organizations in the same } \\
\text { business }\end{array}$ \\
\hline PRT3 & Organizations in related business & 0,875 \\
\hline PRT5 & Online alliances & 0,873 \\
\hline \multicolumn{2}{c}{ Penjualan (Y) } \\
\hline Y1 & Volume Penjualan \\
\hline Y2 & Laba \\
\hline Y3 & Menunjang pertumbuhan \\
\hline Sumber : Hasil Olahan Data (2020) & 0,883 \\
\hline
\end{tabular}

Menurut ( Hair 2017) nilai outer loading di atas 0,50 sudah dianggap cukup untuk memenuhi syarat convergent validity. Menurut hasil data tabel 10 diatas, nilai keseluruhan outler loadingnya sudah diatas 0,5 . Sehingga semua indikator variabel $X$ bauran pemasaran dan Y Penjualan dapat di katakan valid. Dan indicator yang tidak muncul dalam tabel telah dieliminasi karena tidak memenuhi syarat outer loading.

\section{Uji Hipotesis}

\section{Hasil Discriminant Validity}

Table 6

\begin{tabular}{|c|c|c|c|c|c|c|c|c|}
\hline & $\begin{array}{l}\text { PACKAGI } \\
\text { NG \& } \\
\text { PROGRA } \\
\text { MMING }\end{array}$ & $\begin{array}{l}\text { PARTNE } \\
\text { RSHIP }\end{array}$ & $\begin{array}{l}\text { PENJU } \\
\text { ALAN }\end{array}$ & $\begin{array}{l}\text { PEO } \\
\text { PLE }\end{array}$ & $\begin{array}{l}\text { PLA } \\
\text { CE }\end{array}$ & $\begin{array}{l}\text { PRI } \\
\text { CE }\end{array}$ & $\begin{array}{l}\text { PROD } \\
\text { UCT }\end{array}$ & $\begin{array}{l}\text { PROMO } \\
\text { TION }\end{array}$ \\
\hline $\begin{array}{l}\text { PACKAGING \& } \\
\text { PROGRAMMING }\end{array}$ & 0,910 & & & & & & & \\
\hline PARTNERSHIP & 0,840 & 0,870 & & & & & & \\
\hline PENJUALAN & 0,762 & 0,834 & 0,867 & & & & & \\
\hline PEOPLE & 0,783 & 0,798 & 0,819 & 0,844 & & & & \\
\hline PLACE_ & 0,130 & 0,179 & 0,145 & 0,123 & $\begin{array}{r}0,86 \\
2\end{array}$ & & & \\
\hline PRICE_ & 0,263 & 0,342 & 0,301 & 0,323 & $\begin{array}{r}0,55 \\
2\end{array}$ & $\begin{array}{r}0,79 \\
9\end{array}$ & & \\
\hline PRODUCT & $-0,006$ & 0,035 & 0,122 & 0,109 & $\begin{array}{r}0,58 \\
0 \\
\end{array}$ & $\begin{array}{r}0,45 \\
8 \\
\end{array}$ & 0,807 & \\
\hline PROMOTION & 0,696 & 0,777 & 0,763 & 0,774 & $\begin{array}{r}0,09 \\
0 \\
\end{array}$ & $\begin{array}{r}0,42 \\
4 \\
\end{array}$ & 0,098 & 0,802 \\
\hline
\end{tabular}

Sumber : Hasil Olah Data (2020)

Dapat dilihat pada Tabel 12, outer loading indikator pada konstruk lebih tinggi daripada semua cross-loading dengan konstruk lainnya. Selain itu, square root dari AVE masingmasing konstruk harus lebih tinggi dari korelasi tertinggi dengan konstruk lainnya (Fornell-Larcker criterion)

Hasil Determinan $\mathrm{R}^{2}$ 
Table 7

Hasil Uji Determinan $\mathbf{R}^{2}$

\begin{tabular}{ll}
\hline \multicolumn{2}{l}{ R Square } \\
\hline $\operatorname{PENJUALAN}(\mathbf{Y})$ & 0,776
\end{tabular}

Berdasarkan tabel 13 dapat dilihat bahwa nilai $\mathrm{R}^{2}$ dari variabel endogen (Y) adalah 0,776 atau $77,6 \%$ sedangkan $22,4 \%$ sisanya dipengaruhi oleh variabel lain yang tidak diteliti

\section{Hasil Evaluasi Collinearity}

Table 8

Hasil Uji Collinearity

\begin{tabular}{|lr}
\hline \multicolumn{2}{l}{ VIF } \\
\hline Product (X1) & 4,591 \\
\hline Place (X2) & 2,628 \\
\hline Price (X3) & 4,365 \\
\hline Promotion (X4) & 4,275 \\
\hline People (X5) & 5,158 \\
\hline Packaging \& Programming & 3,524 \\
(X6) & 9,778 \\
\hline Partnership (X7) & 5,907 \\
\hline Partnership (X7)
\end{tabular}

Menurut ( Rivera 2020) jika nilai VIF lebih dari sama dengan 10 maka terjadi gejala multikolinearitas, dapat dilihat pada tabel 14 semua indikator memiliki nilai VIF kurang dari 10 sehingga penelitian terbebas dari gejala multikolinearitas.

\section{Hasil Uji Hipotesis}

Table 1

Tabel Hasil Uji Bootstrapping

\begin{tabular}{|c|c|c|c|}
\hline Variabel & P value & $\begin{array}{c}\mathrm{T} \\
\text { Hitung }\end{array}$ & Hasil \\
\hline Product & 0,202 & 1,278 & $\begin{array}{c}\text { Tidak } \\
\text { mendukung }\end{array}$ \\
\hline Place & 0,926 & 0,093 & $\begin{array}{l}\text { Tidak } \\
\text { Mendukung }\end{array}$ \\
\hline Price & 0,236 & 0,186 & $\begin{array}{c}\text { Tidak } \\
\text { mendukung }\end{array}$ \\
\hline Promotion & 0,083 & 1,735 & $\begin{array}{c}\text { Tidak } \\
\text { mendukung }\end{array}$ \\
\hline People & 0,001 & 3,341 & Mendukung \\
\hline Packaging \& programming & 0,527 & 0,633 & $\begin{array}{c}\text { Tidak } \\
\text { mendukung }\end{array}$ \\
\hline Partnership & 0,002 & 3,143 & mendukung \\
\hline
\end{tabular}

Sumber : Hasil Olahan Data (2020) 
Nilai T tabel dalam penelitian ini adalah 1.97824 dengan $\alpha$ sebesar 0.05 dengan jumlah $\mathrm{N} 140$ responden, $\mathrm{k}$ sebanyak variabel, dan nilai $\mathrm{df}=\mathrm{N}-\mathrm{k}$, dimana $\mathrm{N}$ berjumlah 140 dikurangi dengan k sebanyak 9 menghasilkan df yang bernilai 131 .

\section{Pembahasan Hasil Uji Hipotesis}

Hipotesis pertama pada penelitian ini adalah product berpengaruh signifikan terhadap penjualan usaha kuliner. Hasil dari penelitian ini membuktikan bahwa tidak ada pengaruh yang signifikan antara Product dengan penjualan usaha kuliner. Maka kesimpulan dari hasil tersebut adalah bahwa $\mathrm{H}_{1}$ ditolak yang berarti tidak terdapat pengaruh signifikan Product (X1) terhadap Penjualan (Y). Hipotesis kedua pada penelitian ini adalah place berpengaruh signifikan terhadap penjualan usaha kuliner. Hasil dari penelitian ini membuktikan bahwa tidak ada pengaruh yang signifikan antara Place dengan penjualan usaha kuliner. Maka kesimpulan dari hasil tersebut adalah bahwa $\mathrm{H}_{1}$ ditolak yang berarti tidak terdapat pengaruh signifikan placet (X2) terhadap Penjualan (Y). Hipotesis ketiga pada penelitian ini adalah price berpengaruh signifikan terhadap penjualan usaha kuliner. Hasil dari penelitian ini membuktikan bahwa tidak ada pengaruh yang signifikan antara Price dengan penjualan usaha kuliner. Maka kesimpulan dari hasil tersebut adalah bahwa $\mathrm{H}_{1}$ ditolak yang berarti tidak terdapat pengaruh signifikan Price (X3) terhadap Penjualan (Y). Hipotesis keempat pada penelitian ini adalah promotion berpengaruh signifikan terhadap penjualan usaha kuliner. Hasil dari penelitian ini membuktikan bahwa tidak ada pengaruh yang signifikan antara Promotion dengan penjualan usaha kuliner. Maka kesimpulan dari hasil tersebut adalah bahwa $\mathrm{H}_{1}$ ditolak yang berarti tidak terdapat pengaruh signifikan Promotion (X4) terhadap Penjualan (Y). Hipotesis kelima pada penelitian ini adalah People berpengaruh signifikan terhadap penjualan usaha kuliner. Hasil dari penelitian ini membuktikan bahwa ada pengaruh yang signifikan antara People dengan penjualan usaha kuliner. Maka kesimpulan dari hasil tersebut adalah bahwa $\mathrm{H}_{1}$ diterima yang berarti terdapat pengaruh signifikan Peoplet (X5) terhadap Penjualan (Y). Hipotesis keenam pada penelitian ini adalah packaging \& programming berpengaruh signifikan terhadap penjualan usaha kuliner. Hasil dari penelitian ini membuktikan bahwa tidak ada pengaruh yang signifikan antara pengaruh packaging \& progamming dengan penjualan usaha kuliner. Maka kesimpulan dari hasil tersebut adalah bahwa $\mathrm{H}_{1}$ ditolak yang berarti tidak terdapat pengaruh signifikan Pakcaging \& progamming (X6) terhadap Penjualan (Y). Hipotesis ketujuh pada penelitian ini adalah Partnership berpengaruh signifikan terhadap penjualan usaha kuliner. Hasil dari penelitian ini membuktikan bahwa ada pengaruh yang signifikan antara Partnership dengan penjualan usaha kuliner. Maka kesimpulan dari hasil tersebut adalah bahwa $\mathrm{H}_{1}$ diterima yang berarti terdapat pengaruh signifikan Partnership (X7) terhadap Penjualan (Y).

\section{Kesimpulan}

Berdasarkan Hasil dan pembahasan yang telah di bahas pada Hasil dan Pembahasan dapat dilihat bahwa ada 8 faktor yang mempengaruhi Penjualan Usaha Kuliner pada Daerah Tangerang dan Tangerang Selatan, yaitu Product, Place, Price, Promotion, People, Packaging, Programming, Partnership. Semua faktor telah diuji dengan PLS dan dinyatakan Valid dan reliable. Setelah membaca hasil Uji PLS dapat disimpulkan Product (X1) tidak berpengaruh secara signifikan terhadap penjualan pada usaha kuliner dan bukan lah menjadi faktor utama dalam menentukan penjualan, Place (X2) tidak berpengaruh secara signifikan terhadap penjualan pada usaha kuliner dan 
bukan lah menjadi faktor utama dalam menentukan penjualan, Price (X3) tidak berpengaruh secara signifikan terhadap penjualan pada usaha kuliner dan bukan lah menjadi faktor utama dalam menentukan penjualan, Promotion (X4) tidak berpengaruh secara signifikan terhadap penjualan pada usaha kuliner dan bukan lah menjadi faktor utama dalam menentukan penjualan, People (X5) berpengaruh secara signifikan terhadap penjualan pada usaha kuliner dan menjadi faktor utama dalam menentukan penjualan, Packaging (X6) tidak berpengaruh secara signifikan terhadap penjualan pada usaha kuliner dan bukan lah menjadi faktor utama dalam menentukan penjualan, Programming (X7) tidak berpengaruh secara signifikan terhadap penjualan pada usaha kuliner dan bukan lah menjadi faktor utama dalam menentukan penjualan, Partnership (X8) berpengaruh secara signifikan terhadap penjualan pada usaha kuliner dan bukan lah menjadi faktor utama dalam menentukan penjualan. 


\section{Bibliography}

Amana, R. (2020). 80 Persen Hotel dan Restoran di Tangsel Tutup Akibat Pandemi Covid-19, Sejumlah Karyawan Kena PHK. Warkota.Tribunnews. https://wartakota.tribunnews.com/2020/04/13/80-persen-hotel-dan-restoran-ditangsel-tutup-akibat-pandemi-covid-19-sejumlah-karyawan-kena-phk

Badan Pusat Statistik Provinsi Banten. (2020). Pertumbuhan Ekonomi. Economic Journal, 10(45), 114-122.

Creswell, J. W. (2018). Research design qualitative, quantitative, and mixed methods approaches. Sage.

Downes, J., \& Goodman, J. E. (2018). Dictionary of finance and investment terms.

Goeldner, C. R., \& Ritchie, J. R. B. (2017). Tourism : principles, practices, philosophies. Wiley.

Hair, J. F., Black, W. C., Babin, B. J., \& Anderson, R. E. (2019). Multivariate data analysis.

J.F., H., G.T.M., H., C.M., R., K.O., T., C.M., R., M., S., \& M., S. (2017). Mirror, mirror on the wall: a comparative evaluation of composite-based structural equation modeling methods. J. Acad. Mark. Sci. Journal of the Academy of Marketing Science, 45(5), 616-632.

Kotler, P., \& Keller, K. L. (2016). Marketing management.

Metode penelitian pendidikan (pendekatan kuantitatif, kualitatif dan $R \& D$ ) / Sugiyono. (2017).Bandung: Alfabeta. http://opac.library.um.ac.id/oaipmh/../index.php?s_data =bp_buku\&s_field=0\&mod=b\&cat $=3 \& i d=38600$

Morrison, A. M. (2010). Hospitality and travel marketing. Delmar; Cengage Learning.

Rivera, R. (2020). Principles of managerial statistics and data science. https://search.ebscohost.com/login.aspx?direct=true \&scope $=$ site $\& d b=n l e b k \& d b=n$ labk\&AN=2349785

Taufik, \& Ayuningtyas, E. A. (2020). Dampak Pandemi COVID-19 Terhadap Bisnis dan Eksistensi Platform Online (The Impact of Covid-19 Pandemic on Business and Online Platform Existance). Jurnal Pengembangan Wiraswasta, 22(1), 21-32. https://doi.org/10.33370/jpw.v22i1389

Zu, Z. Y., Di Jiang, M., Xu, P. P., Chen, W., Ni, Q. Q., Lu, G. M., \& Zhang, L. J. (2020). Coronavirus Disease 2019 (COVID-19): A Perspective from China. Radiology, 296(2), E15-E25. https://doi.org/10.1148/radiol.2020200490 